\title{
Primary Tumors of the Trachea. Results of Various Forms of Treatment and Review of Tracheal Recons- truction for Primary Tracheal Tumors in Japan
}

\author{
Akira Nonoyama, Tsutomu Osako, Michio Fukunaka, Yukihito Saito, \\ Kazuho Tanaka, Akitoshi Tatsumi, Kazuo Ohmoto, Masao Umemoto, \\ Atoh Masuda, Sumio Kotani and Terumasa Kagawa \\ Department of Thoracic Surgery, Kansai Medical University, Moriguchi, Osaka, Japan
}

\section{Yoshimasa Tanaka}

Department of Radiology, Kansai Medical University, Moriguchi, Osaka, Japan

\section{Haruaki Izumi and Sotokichi Morii}

Department of Pathology, Kansai Medical University, Moriguchi, Osaka, Japan

\begin{abstract}
The present study describes the clinical features and results of various forms of treatment in 6 patients with primary tumor of the trachea, 5 of them with primary tracheal carcinoma. Four of the 5 patients with primary tracheal carcinoma are still living 16 months to 8.5 years after treatment. Two patients who had tracheal reconstruction are alive, 19 and 16 months after surgery. Seventy-nine cases of tracheal reconstruction for primary tracheal tumors are reviewed which have been reported in Japanese literature untill the end of 1982. Circumferential resection of the trachea with end-to-end anastomosis was performed in 11 of 30 patients before 1978, and in 39 of 49 patients since 1979 .
\end{abstract}

Primary tumors of the trachea are relatively rare, and there have been few reports of surgical treatment in Japan. The present study describes the clinical features and results of various forms of treatment in 6 patients with primary tracheal tumor and reviews the present status of tracheal reconstruction for primary tracheal tumor in Japan. 


\section{Materials and methods}

Six patients with primary tumor of the trachea, 5 of them with primary tracheal carcinoma, were treated at our institue from 1968 to 1982.

\section{Primary tracheal carcinoma (5 cases)}

The ages of the 5 patients with primary tracheal carcinoma were 29 to 78 years. The histological diagnosis and sex are listed in Table 1. Two of these patients had epidermoid carcinoma, 2 had adenocarcinoma and one had adenoid cystic carcinoma. The most common presenting symptoms were bloody sputum, dyspnea and wheezing. The duration from onset to diagnosis was 1 month to 1 year. One patient (Case 5) complained of dysphagia and hoarseness and had superior vena caval syndrome. The location and extent of the tumors were determined by tomography, computed tomography and bronchoscopy. In 4 cases the tumor was in the lower third of the trachea and in one in the mid-portion. One case with superior vena caval syndrome (Case 5) had widespread local extension and mediastinal metastasis of the carcinoma. Distant organ metastasis was not observed in any of the 5 cases. Final tissue diagnosis was establised by direct bronchoscopic biopsy in all 5 cases and was confirmed by surgery or autopsy in 3 cases.

Tracheal reconstruction after circumferential resection of the involved trachea with primary end-to-end anastomosis was performed in 2 patients-a 33-year-old woman with epidermoid carcinoma (Case 3) and a 29-year-old man with adenocarcinoma (Case 4). The cervical approach with upper sternotomy was used in Case 3 with the tumor located in the mid-portion of the trachea, and right posterolateral thoracotomy in Case 4. In Case 4, the tumor involved the trachea just above the carina, but the carina was preserved. The tracheal resections were 5 and 6 rings ( 35 and $40 \mathrm{~mm}$ ), respectively, and the trachea was anastomosed by interrupted sutures of 3-0 Dexon. Repeated bronchoscopic resections of the tumor were performed for the 78-year-old woman with adenoid cystic carcinoma in the lower portion of the trachea just above the carina, which occlued about 80 per cent of the lumen, because she refused surgery (Case2). She received systemic and intra-bronchial artery injections of chemotherapeutic drugs. Two patients received irradiation without surgery. A 54-year-old man with epidermoid carcinoma of the lower portion of the trachea just above the carina (Case 1) had Linneac radiation (6000 rads). A 75-year-old man with superior vena caval syndrome (Case 5) received Cobalt radiation (6000 rads) because of extensive disease and advanced age. Cases 3 and 4 received postoperative irradiation. 
Benign tracheal tumor (1 case):

A 35-year-old man with severe dyspnea was admitted emergently because of increased symptoms, and a tumor was noted on the right anterior wall of the upper trachea occluding two thirds or more of the lumen. The tumor, measuring $10 \times 15 \mathrm{~mm}$, was resected immediately with part of thd tracheal wall.

\section{Results}

Four of the 5 patients with primary tracheal carcinoma are still living (16 months to 8.5 years after treatment). Two patients who had tracheal reconstruction are alive, 19 months and 16 months after surgery. Repeated postoperative bronchoscopies have shown no signs of recurrence, although metastases to lymph nodes in the left side of the neck were removed one year after surgery in Case 3. One patient treated with radiotherapy (Case 1) is living 8.5 years later without apparent evidence of disease, and one patient with adenoid cystic carcinoma treated by repeated bronchoscopic removal (Case 2) is alive 5 years later without recurrence. One patient with adenocarcinoma (Case 5) died 2 months after Cobalt radiation; postmorten examination showed carcinomatous invasion of the mediastinum and adjacent lymph nodes, but no grossly visible residual tumor in the mucosa of the trachea.

The 35-year-old man with benign tumor of the upper trachda who underwent emergency surgery is alive about 14 years later without any complications. Postoperative bronchoscopy showed neither tracheal stenosis nor recurrence. The tumor looked malignant macroscopically, but histological examination showed inflammatory pseudotumor.

\section{Discussion}

Primary tumor of the trachea is relatively rare. It has been estimated that one of every 1, 000 patients with cancer has a tumor originating in the trachea ${ }^{1)}{ }^{2)}$, and also that one of every 180 patients with bronchogenic carcinoma or one of every 75 patients with laryngeal cancer has a malignant tracheal tumor ${ }^{3)}$. Malignant tracheal tumors are more frequent than benign ones. In 1958, Gilbert ${ }^{4}$ collected 503 tumors of the trachea in adults, 217 of which were malignant. However, in 1978 , Weber ${ }^{3)}$ reported that of 59 primary tracheal tumors 51 were malignant. Recent reports in the Japanese ${ }^{5) \text { 6) }}$ and English 2) 3) 7) literature indicate that $80 \%$ or more of primary tracheal tumors are malignant.

In cases of benign tumor of the trachea, surgery may not always be necessary, but for patients with severe symptoms such as Case 6, surgical treatment is required. Endoscopic resection is often effective for benign tracheal tumor with symptoms. In Japan, surgery for benign primary tumors of the trachda has been performed in 10 patients, 6 of whom had circumferen- 
tial resection with end-to-end anastomosis : papilloma in 2 cases and leiomyoma, hemangioma, schwannoma, and lipochondroma in one case each.

Successful tracheal reconstructions have often been reported in the English literature ${ }^{8-13)}$, but not in the Japanese. In 1977, Ishihara ${ }^{6)}$ collected 197 cases of surgery of the trachea ; in 37 (19\%) primary tracheal carcinoma was present. Sixty-nine cases of tracheal reconstruction for primary malignant tracheal tumors have been reported in the Japanese literature up to December, 1982 (Table 2). In addition, 10 patients with primary benign tumors had tracheal reconstructions. Circumferential resection of the trachea with end-to-end anastomosis was performed in 11 of 30 patients (36.6\%) before 1978, and in 39 of 49 patients (79.6\%) since 1979 ; in 21 of these $(53.8 \%)$ resections of 5 or more tracheal rings were performed.

It is well known that resection of almost one half of the trachea can be accomplished without difficult, and end-to-end anastomosis can be performed without serious risks. We are in general agreement with reports that more extensive resection with primary anastomosis, as much as 5 $\mathrm{cm}$ of trachea, can be done without the use of a prosthesis and that end-to-end anastomosis is superior to the techniques employing partial patches or prostheses. In cases in which the extent of the resection exceeds the possibility of primary anastomosis, the use of prostheses may be considered. However, the prostheses now available are not perfect because of their low mobility and elasticity or poor tissue-affinity. Therefore, we are hoping for the development of better prostheses.

Endoscopic tumor resection is an important form of palliation. For a patient with adenoid cystic carcinoma, circumferential tracheal resection with end-to-end anastomosis is the treatment of choice. However, for special cases, such as Case 2 with advanced age and poor condition, endoscopic resection of the tumor should be performed as a second choice. Houston ${ }^{3)}$ reported recurrence after as long as 25 years in one case. Therefore, the follow-up period of Case 2 is not loug enongh to predict the ultimate behavior of the tumor.

The use of irradiation for primary malignant tumors of the trachea is controversial, although reports of successfully treated cases of epidermoid carcinoma or adenoid cystic carcinoma ${ }^{2) 14}$ ) 15) have occasionally been seen. Many surgeons believe that irradiation alone is not useful in the treatment of primary tracheal carcinoma. However, in Case 1 with epidermoid carcinoma, irradiation was effective and there has been no reccurrence for over 8 years, and in Case 4, preoperative radiation relieved symptoms, especially bleeding, and consequently tracheal reconstruction was easier. Therefore, the effect of irradiation, more particularly as an adjunct to radical or palliative surgery or endoscopic removal should be investigated more carefully. 


\section{Summary}

The clinical features and results of various forms of treatment in 6 patients with primary tumor of the trachea, 5 of them with primary tracheal carcinoma, are described. Four of the 5 patients with primary tracheal carcinoma are still living (16 months to 8.5 years after treatment), and one patient with benign tumor underwent emergency surgery is alive about 14 years later without any complications. Seventy-nine cases of tracheal reconstruction for primary tracheal tumors have been reported in Japanese literature and circumferential resection of the trachea with end-to-end anastomosis has been performed in about $80 \%$ of surgical cases since 1979.

\section{References}

1) Ranke, E. J., Preslay, S. S. and Holinger, P.H. : Tracheogenic carcinoma. JAMA 182, 519, 1962.

2) Houston, H. E., Payne, W.S., Harrison, E.G. et al : Primary cancers of the trachea. Arch Surg 99, 132, 1969.

3) Weber, A.L. and Grillo, H.C. : Tracheal tumor. Radiol Clin North America 16, 227, 1978.

4) Gilbert, J.G., Mazzarella, L. A. and Feit, L. J. : Primary tracheal tumors in the infant and adult. Arch otolaryngol 58, 1, 1953.

5) Ohiwa, T., Okamoto, T., Yarita, T. et al. : Surgical treatment of tracheal tumors (in Japanese). Kyobugeka 32, 685, 1979.

6) Ishihara, T., Kikuchi, K., Inoue, K. et al : Current clinical data concerning tracheobronchoplasty in Japan (in Japanese). J Jap Assoc Thorac surg 26, 1007, 1978.

7) Hajdu, S. I., Huvos, A.G., Goodner, J.T. et al. : Carcinoma of the trachea : Clinico-pathologic study of 41 cases. Cancer 25, 1448, 1970.

8) MaCafferty, G. J., Parker, L.S., Suggist, S. C. : Primary malignant disease of the trachea. J Laryng Otol 78, 441, 1964.

9) Grillo, H. C. : Circumferential resection and reconstruction of mediastinal and cervical trachea. Ann Surg 162, 374, 1965.

10) Perelman, M. and Korolysova, N. : Surgery of tumors in the thoracic portion of the trachea. Thorax 23, 307, 1968.

11) Pearson, F. G., Thompson, D.W., Weisberg, D. et al. : Adenoid cystic carcinoma of the trachea : Experience with 16 patients managed by tracheal resection. Ann Surg 18, 16, 1974.

12) Grillo, H.C. : Tracheal tumors : Surgical management. Ann Thorac Surg 26, 112, 1978.

13) Olmedo, G., Rosenberg, M. and Fonseca, R. : Primary tumors of the trachea. Clinicopathologic features and surgical results. Chest 81. 701, 1982.

14) Ouchi, M., Yamaguchi, Y., Nishimoto, S. et al. : Adenoid cystic carcinoma of the trachea treated by $\mathrm{CO}^{60}$ (in Japanese). Jap J Chest Dis 33, 753, 1974.

15) Zunker, H. O., Moore, R.L., Baker, D.C. et al : adenoid cystic carcinoma of the trachea. Case report with 9-year follow up. Cancer 23, 699, 1969. 
Table 1 Six patients with primary tracheal tumors

\begin{tabular}{|c|c|c|c|c|c|c|c|}
\hline \multicolumn{2}{|c|}{ Patient } & \multirow{2}{*}{$\begin{array}{l}\text { Histologic } \\
\text { Type }\end{array}$} & \multirow[t]{2}{*}{ Location } & \multirow[t]{2}{*}{ Symptom } & \multirow{2}{*}{$\begin{array}{l}\text { Duration } \\
\text { from Onset } \\
\text { to Diagnosis }\end{array}$} & \multirow{2}{*}{ Trea tment } & \multirow{2}{*}{ Prognosis } \\
\hline Age & Sex & & & & & & \\
\hline 1. $54 \mathrm{yr}$ & $M$ & $\begin{array}{l}\text { epidermoid } \\
\text { carcinoma }\end{array}$ & $\begin{array}{l}\text { lower trachea } \\
\text { (just above } \\
\text { the carina) }\end{array}$ & $\begin{array}{l}\text { bloody sputum } \\
\text { dyspnea }\end{array}$ & $6 \mathrm{mo}$ & $\begin{array}{l}\text { Linneac } \\
\text { radiation } \\
(6000 \text { rads })\end{array}$ & $\begin{array}{l}\text { alive, } \\
8.5 \mathrm{yr}\end{array}$ \\
\hline 2. $78 \mathrm{yr}$ & $F$ & $\begin{array}{l}\text { adenoid } \\
\text { cystic } \\
\text { carcinoma }\end{array}$ & $\begin{array}{l}\text { Tower trachea } \\
\text { (just above } \\
\text { the carina) }\end{array}$ & $\begin{array}{l}\text { dyspnea } \\
\text { cough } \\
\text { fever }\end{array}$ & $4 \mathrm{mo}$ & $\begin{array}{l}\text { Scopical } \\
\text { resection } \\
\text { (3 times) }\end{array}$ & $\begin{array}{l}\text { alive, } \\
5 \mathrm{yr}\end{array}$ \\
\hline 3. $33 \mathrm{yr}$ & $F$ & $\begin{array}{l}\text { epidermoid } \\
\text { carcinoma }\end{array}$ & mid-portion & $\begin{array}{l}\text { bloody sputum } \\
\text { wheezing }\end{array}$ & $5 \mathrm{mo}$ & $\begin{array}{l}\text { Circumferential } \\
\text { resection \& } \\
\text { End-to-end } \\
\text { anastomosis } \\
\end{array}$ & $\begin{array}{l}\text { alive, } \\
19 \text { mo }\end{array}$ \\
\hline 4. $29 \mathrm{yr}$ & M & $\begin{array}{l}\text { adeno- } \\
\text { carcinoma }\end{array}$ & $\begin{array}{l}\text { lower trachea } \\
\text { (just above } \\
\text { the carina) }\end{array}$ & $\begin{array}{l}\text { bloody sputum } \\
\text { dyspnea }\end{array}$ & $1 \mathrm{yr}$ & $\begin{array}{l}\text { Circumferential } \\
\text { resection \& } \\
\text { End-to-end } \\
\text { anastomosis } \\
\end{array}$ & $\begin{array}{l}\text { alive, } \\
16 \text { mo }\end{array}$ \\
\hline 5. $75 \mathrm{yr}$ & M & $\begin{array}{l}\text { adeno- } \\
\text { carcinoma }\end{array}$ & lower trachea & $\begin{array}{l}\text { hoarseness } \\
\text { dyspnea } \\
\text { hemoptys is } \\
\text { SVC syndrome }\end{array}$ & $1 \mathrm{mo}$ & $\begin{array}{l}\text { Cobalt } \\
\text { radiation } \\
(6000 \text { rads })\end{array}$ & dead \\
\hline 6. $35 \mathrm{yr}$ & M & $\begin{array}{l}\text { inflammatory } \\
\text { pseudotumor }\end{array}$ & upper portion & $\begin{array}{l}\text { wheezing } \\
\text { dyspnea } \\
\text { cough }\end{array}$ & $1 \mathrm{mo}$ & $\begin{array}{l}\text { Partial resection } \\
\text { of tracheal wall }\end{array}$ & $\begin{array}{l}\text { alive, } \\
14 \mathrm{yr}\end{array}$ \\
\hline
\end{tabular}

Table 2 Tracheal reconstruction of primary tumors reported in Japanese literature

\begin{tabular}{|c|c|c|c|c|c|c|}
\hline \multirow{3}{*}{$\begin{array}{l}\text { Histologic } \\
\text { Type }\end{array}$} & \multirow{3}{*}{$\begin{array}{l}\text { Surgical } \\
\text { Cases }\end{array}$} & \multicolumn{4}{|c|}{ Surgical Techniques } & \multirow{3}{*}{ Others } \\
\hline & & \multicolumn{2}{|c|}{$\begin{array}{l}\text { Circumferential } \\
\text { resection \& end- } \\
\text { to-end anastomosis }\end{array}$} & \multirow{2}{*}{$\begin{array}{l}\text { Partial } \\
\text { resection } \\
\text { (with or } \\
\text { without patch) }\end{array}$} & \multirow[t]{2}{*}{ Prostheses } & \\
\hline & & $\begin{array}{l}4 \text { rings } \\
\text { or less }\end{array}$ & $\begin{array}{l}5 \text { rings } \\
\text { (or } 4 \mathrm{~cm} \text { ) } \\
\text { or more }\end{array}$ & & & \\
\hline $\begin{array}{l}\text { adenoid } \\
\text { cystic } \\
\text { carcinoma }\end{array}$ & $43(26)$ & $10(5)$ & $16(15)$ & $10(3)$ & $5(2)$ & \multirow[t]{2}{*}{$2(1)$} \\
\hline $\begin{array}{l}\text { mucoepi- } \\
\text { dermoid } \\
\text { carcinoma }\end{array}$ & $7(3)$ & $5(3)$ & 0 & $2(0)$ & 0 & \\
\hline carcinoid & $3(1)$ & $1(0)$ & 0 & $2(1)$ & 0 & 0 \\
\hline $\begin{array}{l}\text { epidermoid } \\
\text { carcinoma }\end{array}$ & $9(6)$ & $3(2)$ & $3(3)$ & $2(1)$ & 0 & $1(0)$ \\
\hline $\begin{array}{l}\text { adeno- } \\
\text { carcinoma }\end{array}$ & $3(2)$ & 0 & $2(2)$ & $1(0)$ & 0 & 0 \\
\hline sarcoma & $3(2)$ & $2(2)$ & $1(0)$ & 0 & 0 & 0 \\
\hline $\begin{array}{l}\text { small cell } \\
\text { carcinoma }\end{array}$ & $1(1)$ & 0 & $1(1)$ & 0 & 0 & 0 \\
\hline $\begin{array}{l}\text { benign } \\
\text { tumor }\end{array}$ & $10(8)$ & $6(6)$ & 0 & $3(1)$ & 0 & $1(1)$ \\
\hline
\end{tabular}

Legend, the numbers in the brackets indicate patients numbers after 1979. 